\title{
Has Social Justice any Legitimacy in Kant's Theory of Right? The EMpirical Conditions of the Legal State as a Civil Union ${ }^{l}$
}

\author{
Nuria Sánches Madrid²
}

\begin{abstract}
This paper aims at shedding light on an obscure point in Kant's theory of the state. It discusses whether Kant's rational theory of the state recognises the fact that certain exceptional social situations, such as the extreme poverty of some parts of the population, could request institutional state support in order to guarantee the attainment of a minimum threshold of civil independence. It has three aims: 1) to show that Kant's Doctrine of Right can offer solutions for the complex relation between economics and politics in our present time; 2) to demonstrate the claim that Kant embraces a pragmatic standpoint when he tackles the social concerns of the state, and so to refute the idea that he argues for an abstract conception of politics; and 3) to suggest that a non-paternalistic theory of rights is not necessarily incompatible with the basic tenets of a welfare state.
\end{abstract}

KEYWORDS: Kant. Right. Poverty. Property. Welfare State.

\section{INTRODUCTION}

Although Kant treated issues concerning social crises as involving corollaries, and not principles, of political right, this does not mean that his rational theory of right has nothing to say about such questions. This paper has three sections. Section 1 explains the rational and ideal basis of the state according to Kant's political philosophy, and how he thinks the legal order can

\footnotetext{
${ }^{1}$ I would like to thank Andreas Michalakis, Melina Mouzalas and Stasinos Staviraneas from the Department of Philosophy of the University of Patras for their helpful suggestions and comments on an earlier draft of this text, discussed with students and professors in this Department in April 2012 during a stay supported by a TS Erasmus mobility scholarship grant accorded by the University Complutense of Madrid. The present version has been written with the support of the Research Project FFI2009-12402, accorded by the MICINN of the Government of Spain, and with a fellowship as Visiting Professor at the Universidade Estadual Paulista (UNESP, Brazil) from June to August 2012, accorded by the FAPESP. I would also like to thank the organizers and participants at the 2012 XIV Colóquio Kant of Campinas (UNICAMP; Brazil) for their helpful remarks on a prior draft of the article. My special thanks goes to Harry Lesser (Univiversity of Manchester) and Jennifer Mensch (Penn State University) for their linguistic assistance to improve this paper.

2 Professora da Faculdade de Filosofia da Universidade Complutense de Madrid, onde ministra cursos principalmente nas áreas de ontologia, metafísica, pensamento italiano e filosofia da ação. Recentemente traduziu para o espanhol o escrito Primeira introdução da Crítica do Juízo de I. Kant (Madrid: Escolar y Mayo, 2011). É membro do Grupo de Pesquisa da UCM “Metafísica, Crítica y Política”. E-mail: nuriasma@ucm.es
} 
be preserved from both social and economic interferences. Section 2 discusses the clash between the requirements for protecting the state and the struggle of individual citizens to obtain the necessary economic basis for happiness. Section 3 gives an account of paternalistic elements in the state, especially of how public care is needed to relieve the poverty of the worse-off. I shall also tackle the topic of distributive justice, in order to assess whether Kant's political thought and, specifically, his account of the grounding of the legal state, could be considered liberal or republican -as Philip Pettit redefined this adjective-, without discarding the convenience of joining the two features under the label of republican liberalism.

Kant identifies the danger that people who have lost their political agency will become a mob, in very similar terms to those used by Hannah Arendt to denounce the dangers of the de-politicization process under totalitarian domination. As Kant points out, this "unruly crowd" will consider itself exempt from the common laws, because its members feel themselves excluded "from the quality of citizen" (Anth, AA 07, p.311). This argument yields the conclusion that the state is not bound to provide security to every citizen facing other human beings, or to be concerned above all with protecting property-owners. On the contrary, the civil union, as classical Greek political theory also claims, entails a form of being together that other associations do not provide, however useful, convenient or even essential they may be from a social point of view. Therefore, the state does not arise, on Kant's view, as a kind of rational justification of existing customs and practices, but is an embodiment of reason itself, which is intended to regulate the way human life in society takes place on the Earth:

A constitution providing for the greatest human freedom according to laws that permit the freedom of each to exist together with that of other (not one providing for the greatest happiness, since that would follow of itself) is at least a necessary idea, which one must make the ground not merely of the primary plan of a state's constitution, but of all the laws too ${ }^{3}$.

$3 \mathrm{KrV}$, A 316/B 373. The references to Kant's Writings are from the Cambridge Edition of the Works of Immanuel Kant, where available. In some cases, I have supplied my own translation. I use the following abbreviations for the most frequently cited works of Kant: KrV: Critique of Pure Reason (in KANT, 1998); PP: Perpetual Peace (In KANT, 1970); Religion: Religion within the Boundaries of mere Reason (In KANT, 1996) and TP: This May Be True In Theory, But It Does Not Apply in Practice (in KANT, 1970). Other Kant's works will be cited using the abbreviations suggested by the Kant Forschungsstelle of the University of Mainz, giving the volume of the Academy Edition and the page. 
As Kant declares in Metaphysics of Morals, the idea of state has a normative value for every form of community (MM, AA VI, p. 313). Moreover, the law, which is both rational and general in its scope, dignifies the sphere of human interaction, by forcing it to develop in accordance with juridical laws ${ }^{4}$. Even if freedom, as "[...] independence from coercive choice of another" ${ }^{5}$, is the unique innate right recognized by Kant's Rechtslehre, this right does not allow any arbitrary development. On the contrary, it requires everyone to submit his or her external freedom to the conditions of a universal law.

The task of law is therefore based on the principle that freedom as independence, the only innate right recognized by Kant, requires the fulfilment of conditions which economic and social commitments must not put in danger.

\section{KANT'S POLITICAL NORMATIVITY AND REASON.}

My assessment starts from a thesis that could hardly be denied, namely the fact that the constitution of a civil union is for Kant an end in itself ${ }^{6}$ and that as such it has to be regarded as a moral duty - exeundum est e statu naturali (Erläuterungen zu Achenwalls Iuris, Refl. 7939, AA 19, p.560)—, which rules the development of all human talents:

$[\mathrm{U}]$ nion of many to some (common) end (which all have) is to be found in all social contracts. But a union of the same which is an end in itself (that each ought to have) $[\ldots]$ is only found in a society in so far as it constitutes a civil condition. ${ }^{7}$

\footnotetext{
${ }^{4}$ This question has been formulated nicely by T. Patrone (2011, p. 130-131): "We saw that the transcendental ideas of reason bring concepts of understanding into a systematic unity, and that hereby provide us with the 'sufficient mark of empirical truth' ( $K r V$, A 651/B 679). Similarly, we can now say, concepts of public right make the rightful use of concepts of private right possible. They make the coherent application of all the claims involving possession possible, and thus provide us with the mark of political truth".

${ }^{5}$ MM, Rechtslehre, AA 06, p.237. See Ripstein’s helpful remark (2006, p.1428) about this issue: “Entering what Kant call 'a civil condition', is not a private transaction at all, but a public one that makes private transactions enforceable".

${ }^{6}$ Mulholland (1990, p.303): "The state is unlike the product of 'social contracts', which are only means through which individuals can pursue their private interests. The state, however, has a universal significance, and is an end in itself". See Weinrib (1992, p.43): "The idea of reason is thus not the blueprint for a distant utopia. Rather, it maps the intelligibility of any truly juridical association".
}

${ }^{7}$ TP, AA 08, p.89. 
As the text above points out, Kant believes that the inclination of human beings to interact with others encourages the beginnings of culture. Even though Kant acknowledges that this inclination is also capable of unleashing an enormous violence, he argues that it deserves to be considered the source of a "[...] disposition to a civil constitution and the public justice" (MAM, AA 08, p.119), according to which, for example, the judgement of crimes committed in a community ceases to be a matter between private individuals, as in the state of nature, to become instead a public issue, under the control of courts appointed by the state. Thus, although the state might be based upon social and economic inequality, civil equality will not be affected. Yet, it is striking the fact that Kant does not express any fear about the possibility that the "order of finances", which Rousseau condemned as a hateful economic system, could prevent some people from attaining the status of active citizens. Indeed, this assumption of the immunity of political rights from any social pressure gives our author licence to claim that inequality is the "[...] source of so many evils but also of everything good" (MAM, AA 08, p.119). Hence, the nature of rights requires that, regardless of social relations having been shaped by an unequal economic status between individuals, the kind of community that free rational human beings are called to set up ought to be governed only by practical reason. In accordance with this, Kant's politics, as a doctrine of right in use [ausübende Rechtslehre] (PP, AA 08, p.370), aims at sheltering human beings only from undesirable social excesses, so that it is not surprising that his political theory regards social competitiveness as a valuable anthropological effect of the development of the skills and talents of humans. Indeed, human beings would prefer to graze like sheep and to be led comfortably by a wise shepherd into a dream world that conceals despotism, cowardice and immaturity, but Nature forces them to strive by themselves to achieve their own social identity, as the Idea of a universal history highlights:

Nature should thus be thanked for fostering social incompatibility, enviously competitive vanity, and insatiable desires for possession or even power. Without these desires, all man's excellent natural capacities would never be roused to develop. Man wishes concord, but nature, knowing better what is good for his species, wishes discord. Man wishes to live comfortably and pleasantly, but nature intends that he should abandon idleness and inactive self-sufficiency and plunge instead into labour and hardships, so that he may by his own adroitness find means of liberating himself from them in turn. The natural impulses which make this possible, the sources of the very unsociability and continual resistance which cause 
so many evils, at the same time encourage man towards new exertions of his powers and thus toward further development of his natural capacities ${ }^{8}$.

Put differently, the autonomy of the legal-political sphere stems according to Kant from the recognition of a general will, with which every legislative operation should conform. Conformity to this general will ensures the property of every citizen and allows each of them to leave a situation where he or she is only acquainted with the mere fact of possession, because only a legal right can make someone the rightful owner of a specific asset. Thus, the perspective opened by the lawgiver acts as a key operator for civil dynamism:

Now, a unilateral will cannot serve as a coercive law for everyone with regard to possession that is external and therefore contingent, since that could infringe upon freedom in accordance with universal laws. So it is only a will putting everyone under obligation, hence only a collective general (common) and powerful will, that can provide everyone this assurance. But the condition of being under a general external (i.e. public) lawgiving accompanied with power is the civil condition. So only in a civil condition can something external be mine or yours.

Corollary. If it must be possible, in terms of rights, to have an external object of one's own, the subject must also be permitted to constrain everyone else with whom he comes into conflict about whether an external object is his or another's to enter along with him into a civil constitution?

This appraisal of the civil union makes the lawgiver the "supreme owner" of the state territory, i.e. a person who puts an end to all controversy regarding property rights and is ultimately responsible for the political effects derived from the economic and financial order of the state. Furthermore, the lawgiver is authorised to compel the citizens with the largest properties to use their surplus wealth to improve the conditions of the needier members of the population. Yet this measure should be considered as a mere parergon or secondary activity for guaranteeing the survival of the civil community as a whole:

On this supreme proprietorship also rests the right to administer the state's economy, finances, and police. Police provide for public security, convenience, and decency, for, the government's business of guiding the people by laws is made easier when the feeling for decency (sensus decori), as negative

\footnotetext{
${ }^{8} \mathrm{IaG}$, IV Proposition, AA 08, p.21.

${ }^{9} \mathrm{MM}$, Rechtslehre, $\$ 8$, AA 06, p.256.
} 
taste, is not deadened by what offend the moral sense, such as begging, uproar on the streets, stenches, and public prostitution (venus volgivaga). ${ }^{10}$

Other passages of the Metaphysics of Morals point towards Hegel, especially in the Philosophy of Right, where he draws attention to the risks that the political exclusion of significant parts of society would entail for the state. In such a context, in Kant's view, taxing those layers of the citizenry that enjoy civil independence would not be an outcome directly following from the nature of political right, but a consequence derived indirectly from the duties that the lawgiver has to abide:

To the supreme commander there belongs indirectly, that is, insofar as he has taken over the duty of the people, the right to impose taxes on the people for its own preservation, such as taxes to support organizations providing for the poor, founding homes, and church organizations, usually called charitable or pious institutions.

The general will of the people has united itself into a society which is to maintain itself perpetually, and for this end it has submitted itself into the internal authority of the state in order to maintain themselves. For reasons of state the government is therefore authorized to constrain the wealthy to provide the means of sustenance to those who are unable to provide for even their most necessary natural needs ${ }^{11}$.

Scholars who have dealt with these passages in Kant, such as Allen D. Rosen, have classified the state's indirect duty to support the poorest people as a duty of beneficence, which would enlarge the scope covered by the duty of benevolence set out in the Groundwork of the Metaphysics of Morals ${ }^{12}$, though assigning it in this case to the state as a person, supplied with its own duties just like an individual. But one should not forget that, when one is concerned with right, "[...] the relation of one's choice to the mere wish (hence also to

\footnotetext{
${ }^{10} \mathrm{MM}$, Rechtslehre, "Effects derived from the nature of the civil union", $₫ \mathrm{~B}, \mathrm{AA} 06, \mathrm{p} .325$.

${ }^{11}$ MM, Rechtslehre, "Effects derived from the nature of the civil union", $\$$ C, AA 06, p.326.

${ }^{12}$ For example, passages like the following (GMS, AA 04, p.423): “[i]f no one can rationally will the maxim of never helping others as a law of nature [...] then neither can an entire people rationally will as a law of political society that the state should allow them to perish rather than supply their basic needs. The same reason that makes it impossible rationally to will the maxim of never helping others as a law of nature also makes it impossible rationally to consent to a law of political society that would permit the state to ignore the basic need of its citizens". See Rosen (1993, p.173-208). Cfr. MM, Tugendlehre, $\$ 30$, AA 06, p.453.
} 
the mere need) of others, as in actions of beneficence, does not signify" (MM, AA 06, p.230). Hence, the legal corpus that makes a lawless mob to become a people ${ }^{13}$ does not rely on the faculty of choice [Willkür] of one or more human beings, but it derives from the general will [allgemeiner Wille], which confers legal objectivity on the acts, properties and capacities of a citizen after declaring them compatible with the exercise of freedom by other citizens.

Therefore, it is not surprising that, according to Kant, only temporary contributions should be enforced by the legal state. In fact, " $[\ldots]$ this arrangement does not make poverty a means of acquisition for the lazy (as is to be feared of religious institutions), and so does not become an unjust burdening of the people by government" (MM, AA 06, p.326). It is worth noting that this passage from the Metaphysics of Morals does not take into account the material conditions necessary for the individual citizens' survival, but only those required for the survival of civil unity, for the citizenry considered as one indivisible body. Naturally, it is difficult to separate completely the survival of the civic body and that of the citizens, but it is crucial for the Kantian argument that one or the other has the priority. Since the state must guarantee the survival of the citizenry, in extreme circumstances it can be necessary to control the expansive dynamics of economic development. Thus, because the state must proceed to preserve the whole civic body, it cannot ignore the material life conditions of each citizen. Kant puts this in terms very similar to those in which he argues, in the Doctrine of Virtue, that there is a moral obligation to take care of one's own body. Indeed, the Doctrine of Virtue also treats maintaining the physical integrity of the human body as an indirect duty regarding human moral behaviour (MM, Tugendlehre, $\$ 19$, AA 06, p.388). Nonetheless, it must be recognized that when citizens' lives are a concern in the public sphere, one can be sure that politics has fallen into a period of possibly fatal crisis, since this demonstrates that economic activity has become

\footnotetext{
${ }^{13}$ Regarding the conditions of this transformation, which Kant does not hesitate to compare with the development of an organism, see S. Meld Shell (2011, p.232-233): "States are the vehicle through which a people becomes a nation. All states are nation-states [...] Citizens, according to Kant's adaptation of ancient and a more recent political concept, are familiarly related in a double sense: first, as still-savage children, as it were, of a common soil; second, as jointly ennobled sons of the republic. Without this shared double 'natality', for which being human is not enough, men, in their capacity as pure moral beings, would hover over the world like angels (to borrow a concept from Pierre Manent). A juridical man is an embodied man (a 'child of the earth') who takes up space and thus comes potentially into conflict with other human beings. Everyone excludes others from some portion of the globe, beginning with the place where he or she is born. People arise, in both fact and right, from the debt of support that parents owe their children. Kant's account of citizenship acknowledges this debt (to which myths as 'autochthony' fictionally attest), while subordinating to an ideal of civic re-creation".
} 
a serious threat to the civil condition. This is all that Kant has to say about the attention that the state ought to pay to the overall economic status of its population, a task that has nothing to do with the alleged hypothesis that the state should despotically shape the happiness of citizens.

\section{Salus CiVtTatis and Happiness}

The enigmatic passage in which Kant defines the right of the state to tax the citizenry in order to support the poorest people does not aim at blurring the tasks that the jus publicum has to take over with those of the institutions charged with supplying every citizen with the conditions for happiness that he is entitled to ${ }^{14}$. Other of Kant's texts, such as the following, keep carefully separated the spheres of external freedom and the struggle for happiness:

The concept of an external right derives entirely from the concept of freedom in the external relations of human beings to one another and has nothing whatever to do with the end that all human beings have by nature (the goal of happiness). ${ }^{15}$

Indeed, any state providing such treatment to their citizens would convey an unbearable paternalistic agency ${ }^{16}$. Kant does not spare appeals to the poor in order to convince them to resolve the problem of educating their offspring on their own, since attaining economic autonomy is equated with claiming one's own civil maturity:

In the right of the state the principle of the constitution is not the happiness of citizens (for they can take care of it by themselves), but their rights. The welfare of the whole is only the means to secure the right and place them under the conditions by which they could make themselves happy in every possible way. Hence, the poor also have to deal with the maintenance of schools and they have to educate their children themselves,

\footnotetext{
${ }^{14}$ R 7430, AA 19, p. 372: "The health of the state is entirely different from that of a people. The first refers to the whole with respect to its subordination under laws and to the administration of justice; the second one refers to the private happiness of each one. To take care of the latter belongs to the merits of a prince".

${ }^{15}$ TP, AA 08, p.283.

${ }^{16}$ V-NR/Feyerabend, AA 27/2, p.1360: "The opinion of caring citizens and their happiness as parents may be completely in contradiction with the principle of law, civil liberty".
} 
besides having the freedom to determine for themselves their religion, and only change it by consent ${ }^{17}$.

Yet these recommendations, which suggest a particular idea of the development of a society, are not directly concerned with issues of distributive justice and the allocation of goods. In fact, the welfare of the state is not identical with that of individuals, and thus while dealing with the private happiness of one's subjects could be part of the merits of a prince, it will be hardly one of his duties. But although public welfare, attained by the rule of justice, and individual well-being are not identical, it is unsurprising that in order to achieve public welfare one must sometimes takes measures to improve the welfare of particular citizens. The state should not proceed in this way to please human beings for sentimental reasons, but with the intention of providing the state with the cohesion necessary in every commonwealth. This particular issue is emphasized in this excerpt from Theory and Practice:

If the supreme power makes laws directed primarily toward happiness (the prosperity of citizens, increasing population, and so on), this does not happen because it is the purpose of establishing a civil constitution. Instead, it is merely a means for securing the state of right, especially against the people's external enemies. [...] The purpose is not, as it were, to make the people happy against their will, but only to make them exist as a commonwealth ([...] for unless the peoples are prosperous, the nation will not possess strength enough to resist external enemies or to maintain itself as a commonwealth). ${ }^{18}$

These texts demonstrate the legitimacy of the supreme lawgiver to survey and alter the economic situation of some citizens, in order to correct hazardous social disadvantages for the civil community as a whole. However, is Kant's commitment to republicanism clear enough to embrace the coordinates of corrective or distributive justice, as formulated by authors such as J. Rawls or T. Pogge? We cannot share the ease with which V. Gerhardt, for example, states that actions in line with a Welfare State follow naturally from the tenets

\footnotetext{
${ }^{17}$ R 7938, AA 19, p.560.

${ }^{18}$ TP, AA 08, p.298-299, note.
} 
of Kant's doctrine of right ${ }^{19}$. W. Kersting and B. Ludwig ${ }^{20}$, amongst other Kant scholars, have delivered accounts that have problematized Kant's attitude toward the Welfare State. Consider the following remarks by Kersting:

The Kantian state is, to be sure, limited to the functions of the realization of right and the protection of freedom, but when one considers the dangers that threaten right, freedom, and the dignity of humans from a marketplace unsupervised by a social state and from radical libertarianism's politics of minimal state restriction, then one sees that the philosophy of right must require a compensatory extension of the principle of the state or right through measures toward a social and welfare state in the interest of the human right of freedom itself. Kant's philosophy of right is thoroughly compatible with the concept of a social state in the service of freedom. But this extension of Kant's philosophy of right by no means revokes its pervasive antipaternalism ${ }^{21}$.

Kersting's convincing argument indicates the shortcomings of Kant's doctrine of right from the point of view of social justice, insofar as he ascribes only a prudential aim to the public duty to support poor people. Here it should not be forgotten that while Kant considers social inequality to be a result of differences in the development of human potential, as stated earlier, that social inequality is not regarded as threatening the autonomy of the political sphere, since only the latter can provide meaningful and purposive equality. Considerations of social justice change, however, when what is at stake is ensuring the survival of the community (see AA 08, p.298), as Kersting thoughtfully argues:

The interests of the individual self-preservation only call the attention of the philosophy of law when their negligence could destabilize the community and jeopardize the conservation of right. Therefore, the assistance of the welfare state is not grounded on a right to the livelihood of individuals,

\footnotetext{
${ }^{19}$ V. GERHARDT (1984, p.84): "[Kant displays] opportunities to support from the point of view of the political right social state measures".

${ }^{20}$ B. LUDWIG, 1993, p.234-235 and 253: "[U]nder the Kantian approach, promoting material equality and individual welfare is neither an aim nor a mediate consequence of the civil constitution. [...]

[T] he minimal conditions of a state of civil constitution are limited in the best steady legal relations and serve to maintain the state as a place of the fulfilment of right and in no event to promote the welfare of individual citizens. [...]

I hope to have shown that those who seek a theory of social justice, which provides the criteria for the redistribution of the results of social cooperation, have to leave for the time being without the company of Kant".
}

${ }^{21}$ KERSTING, 1992a, p.356-357. 
but on the right of subsistence of the right itself, which, in turn, is exclusively the institutional expression of law principles of freedom. The indirect duty of the state to preserve the existence of dispossessed citizens is the price to be paid by the right itself, in case he wishes to be applied in a concrete space and time, and in case it wishes to gain power of organization and to exist under different empirically verifiable conditions. But that means that the welfare state is not a legal concept, but only a prudent instrument, that is, attentive to the reality of the exercise of right. ${ }^{22}$

Thus, social inequality will be tolerated provided that it does not endanger the equality of citizens before the law, which is one of the bases of civil union. Hence, the supreme owner will not be acting against right and justice if he decides to redistribute wealth because he judges such an action to be necessary for the survival of those who have nothing or little $e^{23}$. Were the supreme lawgiver to take the same decision on behalf of the happiness of a group of human beings, it would be a clear meddling in the economic life of the population, and consequently, the movement of right into bio-politics, a danger which Kant was not even remotely able to forecast. So long as the lawgiver is only reacting to an extreme social situation, his measures toward the civil body are an effort to keep itself alive, just as one would an organism. It should not be forgotten that Kant compares the constitution of a nation into a state with the development of a living organism, in the third Critique ${ }^{24}$. However, Kant's theoretical construction protects politics from such social interferences:

This uniform equality of human beings as subjects of a state is, however, perfectly consistent with the utmost inequality of the mass in the degree of its possessions, whether these take the form of physical or mental superiority over others, or of fortuitous external property and of particular rights (of which there may be many) with respect to others. Thus the welfare of the one depends very much on the will of the other (the poor depending on the rich), the one must obey the other (as the child its parents or the wife her husband), the one serves (the labourer) while the other pays, etc.

${ }^{22}$ KERSTING, 2003, p.127 [my translation]; cfr. Idem, 1992b, 143 and 164, n. 7.

${ }^{23}$ Mulholland has identified shrewdly this point (see 1993, p.318): "By taking over the control of land, the state thwarts the individual's title to achieve land necessary for existence, and so must provide the means for existence in the case of the needy. [...]

Only acquirable property can be regarded as owned by the commonwealth as such. Innate property (including one's natural abilities) is not common property. Accordingly, while individual may be treated unfairly by nature, the state may not rightfully interfere with this distribution, since its province of control lies only in the area of external objects and their distribution". Cfr. ROSEN, p. 206-207.

${ }^{24} \mathrm{Vd} . K U, \S 65, \mathrm{AA} 05$, p.375. 
Nevertheless, they are all equal as subjects before the law, which, as the pronouncement of the general will, can only be single in form, and which concerns the form of right and not the material or object in relation to which I possess rights. ${ }^{25}$

The reluctance displayed by scholars like Ludwig and Kersting regarding the place that public care of the poorest should have within Kant's theory of the legal state is supported by Kant himself, as the previous extract shows clearly. As I claimed above, the point here is not the intention of one private subject to benefit another, but a much more impersonal measure of balances, almost mechanical ones, whose aim is to protect the whole body of a state. More accurately, one may say that the systematic character of public attention devoted to poverty leads Kant to distrust the benefits of charity, since the latter describes an operation little interested in the common good and, to this extent, unable to fight against the state's tolerance for inequality. According to Kant's argument, without a better solution, wealthy citizens should undertake this task, since such behaviour would partially correct the injustice of monopolized wealth ${ }^{26}$. That said, individuals could never take over a function that the State ought to properly carry out ${ }^{27}$.

\section{The Kantian Definition of a Paternalistic State}

The texts quoted above have shown by that Kant's theory rejects every form of paternalism. Yet, it provides a crucial link between, on the one hand, the right of every human being to secure their existence and on the other

\footnotetext{
${ }^{25}$ TP, AA 08, p.291.

${ }^{26}$ Kant also gives instructions to those citizens who would practice beneficence, as the reader can see in MM, Tugendlehre, $\$ 31$, AA 06, p.454: "Up to where we should spend our goods to charity? Of course, not so much to end up needing charity ourselves. [...] The ability to do the good that depends on wealth is largely the result that many men are favoured by the injustice of the government, which introduces an inequality of wealth that makes necessary the charity of others. In such circumstances, the assistance that the rich could provide to the needy people, worth it the name of charity, which he [the rich] boasts so readily as a merit of?" On the basis of Kant's observations about the proper attitude of the legislator in dealing with poverty, I cannot agree with Rosen (1996, p.179): "[T]he ruler's duty of benevolence is derived from, without reducing or eliminating, private citizen's duties of benevolence".

${ }^{27}$ I agree completely with the following remark of Ripstein (2006, p.1430): "Kant argues that provision for the poor follows directly from the very idea of a united will. He remarks that the idea of a united law-giving will requires that citizens regard the state as existing 'in perpetuity'. By this, he does not mean to impose an absurd requirement that people live forever, but rather that the basis of the State's unity - the ability of the State to speak and act for everyone — survives changes in its memberships".
} 
hand, the creation of a state that cannot remain indifferent to the fact that certain individuals lack all access to the struggle for civil independence. The point is not that the state should turn passive citizens into active ones, to citizens who would be "co-legislators" of the state (MM, AA 06, p. 314). If political institutions did this, they would be encroaching on the functions of free human agency. On the contrary, the state ought rather to be responsible for preventing a situation wherein entire sections of society would lack any possibility of gaining political agency. Those who are not their own master can be only subjects of the state, as part of the community and co-beneficiaries of its protection, but not really members of it. Of course, this presupposes that the acquisition of active citizenship is a desirable goal for all rational beings. How might this agree with Kantian republicanism? Certainly, it should be noted that Kant dismisses aristocratic privileges as a criterion of full citizenship ${ }^{28}$ : "[...] no one can bequeath to his descendants the prerogative of the rank which he has within a commonwealth" (TP, AA 08, p. 293) proves this. The allocation of priority to self-employment, instead of to leisure or inheritance, confirms that Kant is thinking about a society led by the bourgeoisie instead of the aristocracy ${ }^{29}$. In this social context, servants or odd-jobbers cannot live without the support of people who are active members of the commonwealth (AA 06, p. 315). But it does not seem that according to Kant this exclusion from the civil order would be a permanent fait accompli. Passages like the following make a clear objection to this:

I cannot really reconcile myself to [expressions such as] "The bondmen of a landed proprietor are not yet ready for freedom" [...] For according to such a presupposition, freedom shall never arrive, since we cannot ripen to this freedom if we are not first of all placed therein (we must be free in order to be able to make purposive use of our powers in freedom). ${ }^{30}$

This passage reminds us that the experience of freedom should not be limited to those belonging to a specific social status. I consider the distinction

\footnotetext{
${ }^{28}$ See TP, AA 08, p.292: "Every member of a commonwealth must be allowed to attain any level of rank within it (that can belong to a subject) to which his talent, his industry and his luck can take him; and his fellow subjects may not stand in his way by means of a hereditary prerogative (privileges [reserved] for a certain rank), so as to keep him and his descendents forever beneath the rank". R. Beiner guesses (2011, p.212) that TP (AA 08, p.296-297) adopts the point of view of the lawgiver, not that of the citizen, whereas MM (AA 06, p.314) focuses on the real civic status of each individual, which the right to vote expresses better than any other capacity.

${ }^{29}$ Vd. S. MELD SHELL (1980, p. 158).

${ }^{30}$ Religion, AA 06, p.188.
} 
suggested by Richard E. Flathman between a "high-liberal" and a "low-liberal" theory of citizenship quite useful ${ }^{31}$; and according to it I claim that Kant's account is "high-liberal", since his philosophy of right suggests that human dignity requires that people are provided with a civil identity. Certainly, the achievement of civil status expresses the essence of human community.

So the supreme owner of the country, the supreme ruler of the state, acts according to the general will when he intervenes directly in order to redistribute the private wealth of the citizens, reminding all the individual owners, thereby, that their ownership of property is a consequence of the rational civil covenant $^{32}$, not of some previous empirical appropriation. In order to shed some further light on this question, E. J. Weinrib suggests considering the Welfare State not as a right within the Kantian system of rights, but as a benefit derived from a juridical duty:

$[\mathrm{P}]$ roperty and the public duty to support the poor are connected through a single sequenced argument that extends the reach of the universal principle of right while preserving consistency with the ideas of rightful honour, innate equality and non-dependence that this principle implies. For Kant, taxation is not theft, and neither is property. On the contrary, the two are jointly necessary for a civil condition. On Kant's view as I have reconstructed it, the public duty to support the poor is latent within private property as a rightful institution ${ }^{33}$.

\footnotetext{
${ }^{31}$ See FLATHMAN (1995) and the good comments of Lucas THORPE (2010, p.483, n. 57).

${ }^{32}$ Mulholland has seen this point with accuracy (1990, p. 317 and 395): "In the light of this obligation to provide welfare, it should also be recalled that all individual rights to property are consequences of acts of the a priori general will which permits private possession. The state, however, represents this general will and makes it effective. As a result, the state must be regarded as the original public owner of all its territory and everyone's right to land must be conditional on the judgement of the political authority so long as the constitution of this state accords with the rightful attributes. The state may, therefore, tax and to some degree redistribute wealth. [...]

Because the general will control all land, the state, in making specific decisions that it means to accord with the general will, has the obligation to ensure that its administration does not violate the right of freedom. But it can do this only by the provision of public welfare. The important point to see here is that needy members of the community have the right to welfare. [...]

$[T]$ he state is not merely exercising benevolence in taxing its wealthier members to provide for the needs of the poor. Those wealthy members can achieve their wealth only through the cooperation provided by the original (a priori) act of the production of the general will. They may not claim that their right to property precedes and is independent of the general will, for one can have even a provisional right only if one agrees to submit to a civil condition".

${ }^{33}$ WEINRIB, 2003, p. 828.
} 
In accordance with this approach, the state's contribution to the progressive elimination of poverty would be a consequence of the legal institution of private property as a condition of civil independence. I find Weinrib's formulation superb, since it argues that the public duty to protect the poor is a development implied by Kant's doctrine of private right, that is, a consequence of his rational grounding of property. The inequality produced by the economic and commercial development of nations does not alter the fact that "[e]very human being has an innate right to be in some place on the earth, for his existence is no deed (factum) hence no wrong (iniustum)" (Zur Metaphysik der Sitten (Nachlass), AA 23, p. 279). The following quotation makes it clear that any libertarian deviation of economy might violate the inalienable right of all people to see their material survival ensured en against external threats, such as lack of food, shelter or any other basic conditions for human development:

[T] hrough the innate possession of the earth, I exclude everyone from that use of the same which is necessary for the preservation of my existence (thus not through my mere will)..$^{34}$

So, for Kant, economic activity should never become a sphere that threatens the material survival of people. Indeed, if something like that were ever implied, it would put the economy in direct competition with the political sphere, and it is well known which side Kant would be on. Economic mechanisms allow the property and other assets of the citizens to increase unequally, depending on the capabilities of each one; but there must be limits put on this. In support of this thesis it is helpful to recall that Kant's definition of human being is not socio-economic, but political. Claiming that a human being is not only an animal, as Kant's Anthropology states, entails that humans need political forms free from the pressure of the empirical social milieu. Therefore, young people must be educated in the idea that equality among people is a rational principle which underlies the social inequality that they notice in their milieu, so that they do not consider it as a matter of destiny or fate. On the contrary, they should be taught that social inequality stems from the radical human tendency to extract profit from each other (PÄD., AA 09, p. 498), a situation that it would not be just to prevent but which it is necessary and right to keep in check.

${ }^{34}$ Zur Metaphysik der Sitten (Nachlass), 23, p.286. 
So far, I have tried to show that moral and legal grounds support the commitment of the state to help both the politically disenfranchised and the poor, as Kant says:

The very poor must be fed, and if they are children, must be cared for. Why? Because they are men, not beasts. This does not stem from the right of the poor as citizens, but from their needs as men. [...] Who has to feed them? The question is not whether the state or the citizen. For if it is the state that feeds them, so does it also the citizen, but whether it hangs on the free will of the citizen or on coercion, that is, on a gift or on a contribution. ${ }^{35}$

Assessing the legitimacy of social justice in Kant's doctrine of right does not requires us to subsume this theory to a pragmatic condition that would ruin its theoretical purity. On the contrary, Kant's comments about the public commitment to social troubles are quite far from a pragmatic hybrid solution that would condemn the state to take care of certain disadvantaged classes. Thereby, I would suggest considering this extreme measure as the corollary of a theory based on reason. The statement Fiat iustitia, pereat mundus held in Perpetual Peace ${ }^{36}$ might also be understood in the following sense, that no worldly device, whether economic, social or cultural, may give lessons to the state in order to provide justice. By contrast, the utilitarian arguments of the business world belong to the sphere of physical laws, which also contains only technical-practical propositions, according to Kant's division of philosophy, but they never belong to the moral and political one. Moreover, paternalistic despotism, which every republican government must avoid, does not arise only when the subjective sense of happiness prevails over the common good fostered by the state. For the interests of economic corporations and affairs, even those which could become of "national interest", serve only to materialize particular purposes, and not the common good. Following a line of argu-

${ }^{35}$ Notes on Achenwall, Iuris naturalis pars posterior, $\$ 130$ "De iure circa fecilitatem publicam", 19, p. 578.

${ }^{36}$ PP, AA 08, p.379: "This proposition [fiat iustitia, pereat mundus] simply means that whatever the physical consequences may be, the political maxims adopted must not be influenced by the prospect of any benefit or happiness which might accrue to the state if it followed them, i.e. by the end which each state takes as the object of its will (as the highest empirical principle of political wisdom); they should be influenced only by the pure concept of rightful duty; i.e. by an obligation whose principle is given a priori by pure reason. The world will certainly not come to an end if there are fewer bad men. Moral evil has by nature the inherent quality of being self-destructive and self-contradictory in its aims (especially in relations between persons of a like mind), so that it makes way for the moral principle of goodness, even if such progress is slow". 
mentation repeatedly explored by H. Arendt, I would say that Kant's doctrine of right, and his notion of civil union, anticipate the possibility that "social paternalism" would be much worse than "state paternalism". Although the state is expected to enlighten civil society, Kant acknowledges that at times the reverse has to be the case, so that private initiatives and intellectual efforts deprived of any academic endorsement are burdened with the task of drawing the outline of how the state can become the state that ought to be. Obviously, Kant could not foresee the problems that the state would have in circumstances that he did not know, like those of advanced capitalism. One can guess with some legitimacy that he would have discerned in the arguments of the present powerful industrial and financial trusts the interests of "monumental individuals"; individuals who, in effect, argue as frightening subjects, since they are no longer limited by birth and death, and are thus able to understand organic development only in terms of an infinite accumulation.

Finally, I want to claim that the blame placed on politicians for their effort to articulate only the legitimate path to freedom and happiness while excluding all others, might be better understood as a critique addressed not only to political rulers, but also and especially to the socio-economic structures that encompass public space, imposing their own interests and their own vision of happiness on the whole civil body:

No one can compel me to be happy in accordance with his conception of the welfare of others, for each may seek his happiness in whatever way he sees fit, so long as he does not infringe upon the freedom of others to pursue a similar end which can be reconciled with the freedom of everyone else within a workable general law i.e. he must accord to others the same right as he enjoys himself. A government might be established on the principle of benevolence towards the people, like that of a father towards his children. Under such a paternal government (imperium paternale), the subjects, as immature children who cannot distinguish what is truly useful or harmful to themselves, would be obliged to behave purely passively and to rely upon the judgement of the head of state as to how they ought to be happy, and upon his kindness in willing their happiness at all. Such a government is the greatest conceivable despotism, i.e. a constitution which suspends the entire freedom of its subjects, who thenceforth have no rights whatsoever. ${ }^{37}$

As I pointed out before, the sharp distinction between happiness and freedom included in Kant's doctrine of right does not assign to the state the

${ }^{37}$ TP, AA 08, p. 290s. 
direct task of turning passive citizens into active ones. The dignity of the rational subject prevents treating someone as a simple subordinate. However, the state must nevertheless take unavoidable measures when social breakdown threatens the survival of the civil body itself. One consequence of this, however, when considering that businesses and company aggregates might similarly enter into crisis, and deserve the same support and help as that devoted to individuals, is that the citizenry would fall victim to a terrible political illusion. An illusion that would illegitimately dignify elements of social life by granting them the character of a person, threatening thereby the specifically human capacity to act autonomously (MM, AA VI, p.392). Indeed, in such a case, in a short time policy would be restricted in an astonishing manner, being limited to managing the governance of economic "concrete orders" in the sense labelled by Carl Schmitt, however postmodern, decentralized and flexible they might be. And as a result of it the state would become a mere subordinate in service to the genuine sovereign, and the "wild powers" would have seized political control.

MADRID, Nuria Sánches. Tem a Justiça Social Alguma Legitimidade na Teoria Kantiana do Direito? As Condiçóes Empíricas do Estado de Direito como União Civil. Trans/Form/ Ação, Marília, v. 37, n. 2, p. 127-146, Maio/Ago., 2014.

RESUMO: $O$ presente artigo tenciona contribuir a esclarecer uma questão, tâo complicada quanto polêmica, no âmbito da teoria kantiana do Estado de direito. Pretendo submeter à discussão se a teoria racional de Kant sobre o Estado legal sustenta ou rejeita o fato de que certas situaçóes sociais excepcionais, como a extrema pobreza de uma parte da população, requerem o apoio institucional do Estado para garantir a consecução de um limiar mínimo de independência civil. Proponho-me os três seguintes objetivos: 1) argumentar a capacidade da doutrina kantiana do direito para propor soluçóes para a difícil relação entre economia e política, no tempo presente; 2) mostrar que o ponto de vista pragmático que Kant adota quando analisa as preocupaçóes sociais do Estado recusa a ideia segundo a qual Kant sustenta uma concepção abstrata da política e 3) sugerir a tese de uma teoria não paternalista do Estado de direito sem ter que renunciar necessariamente aos princípios básicos do welfare state.

PALAVRAS-CHAVE: Kant. Direito. Pobreza. Propriedade. Welfare State.

\section{REFERENCES}

BEINER, R. Paradoxes in Kant's account of citizenship. In: PAYNE, C.; THORPE, L. (Eds.). Kant and the concept of community. Rochester, NY: University of Rochester Press, 2011. p. 209-225. (NAKS Studies in Philosophy, v.9). 
DOTTI, J.E. Observaciones sobre Kant y el liberalismo. Araucaria, n. 13, p. 4-12, 2005.

FLATHMAN, R.E. Citizenship and authority: a chastened view of citizenship. In: BEINER, R. (Ed.). Theorizing citizenship. New York: State University of New York Press, 1995. p. $105-151$.

GERHARDT, V. Wohlgeordnete Freiheit. Berlin, 1984. Rezension von W. Kersting. Allgemeine Zeitschrift für Philosophie, v. 11, n. 2, p. 79-84, 1986.

KANT, Immanuel. Kants Gesammelte Schriften. Ed. Königlich Deutschen Akademie der Wissenschaften. Berlin: De Gruyter, 1902-.

Kant's political writings. Ed., introd. and notes by H. Reiss. Translated by H.B. Nisbet, Cambridge: Cambridge University Press, 1970.

. Writings on religion and rational theology. Ed. A. Wood and G. di Giovanni. Cambridge: Cambridge University Press, 1996a.

$1996 b$.

.Metaphysics of Morals. Translated by M. J. Gregor. Cambridge: Cambridge U.P.,

Critique of pure reason. Trans. P. Guyer and A. Wood. Cambridge: Cambridge University Press, 1998.

. Anthropology, history, and education. Ed. G. Zöller and R. Louden. Cambridge: Cambridge University Press, 2007.

KAUFMAN, A. Welfare in the Kantian state. Oxford: Clarendon Press, 1999.

KERSTING, W. Politics, freedom, and order. In: GUYER, P. (Ed.). The Cambridge companion to Kant. Cambridge: Cambridge University Press, 1992a. p. 342-366.

. Kant's concept of the state. In: WILLIAMS, H. L. (Ed.). Essays on Kant's political philosophy. Chicago: University of Chicago Press, 1992b. p. 143-165.

. Kant e o problema da justiça social. Veritas, v. 48, n. 1, p. 121-136, 2003.

LEBAR, M. Kant on Welfare. Canadian Journal of Philosophy, v. 29, n. 2, p. 225-250, 1999.

LUDWIG, B. Kants Verabschiedung der Vertragstheoriekonsequenzen für eine Theorie sozialer Gerechtigkeit. Jahrbuch für Recht und Ethik/Annual Review of Law and Ethics, v. 1, p. 221-254, 1993.

MELD SHELL, S. The Rights of reason: a study of Kant's philosophy and politics. Toronto: University of Toronto Press, 1980.

Kant's conception of the Nation-State and the Idea of Europe. In: PAYNE, C.; THORPE, L. (Eds.). Kant and the concept of community. Rochester, NY: University of Rochester Press, 2011. p. 226-244. (NAKS Studies in Philosophy, v.9)

MULHOLLAND, L. Kant's system of rights. Tennessee: Columbia University Press, 1990. 
NOUR, S. A filosofia social de Kant. Philosophica, São Cristóvão, v. 4, p. 39-56, 2003.

NOZICK, R. Anarchy, State and utopia. New York: Basic Books, 1974.

PATRONE, T. Kant's Rechtslehre and ideas of reason. In: BAIASU, S.; PIHLSTRÖM, S.; WILLIAMS, H. (Eds.). Politics and metaphysics in Kant. Cardiff: University of Wales Press, 2011. p. 115-133.

RAWLS, J. Theory of justice. Oxford: Oxford University Press, 1971.

RIPSTEIN, A. Private order and public justice: Kant and Rawls. Virginia Law Review, v. 92, n. 7, p. 1391-1438, 2006.

ROSEN, A.D. Kant's theory of justice. Ithaca: Cornell University Press, 1993.

Rousseau, J.-J. The Social contract and other later political writings. Ed. and trans. by V. Gourevitch. Cambridge: Cambridge University Press, 1997.

THORPE, L. Is Kant's realm of ends a unum per se? Aquinas, Suárez, Leibniz and Kant on composition'. British Journal for the History of Philosophy, v. 18, n. 3, p. 461-485, 2010.

WEINRIB, E.J. Poverty and property in Kant's system of rights. Notre Dame Law Review, v. 78, n. 3, p. 798-828, 2003.

. Law as idea of reason. In: WILLIAMS, H. L. (Ed.). Essays on Kant's political philosophy. Chicago: University of Chicago Press, 1992. p. 15-49.

Recebido em: 30/12/13

Aceito em: $13 / 01 / 14$ 